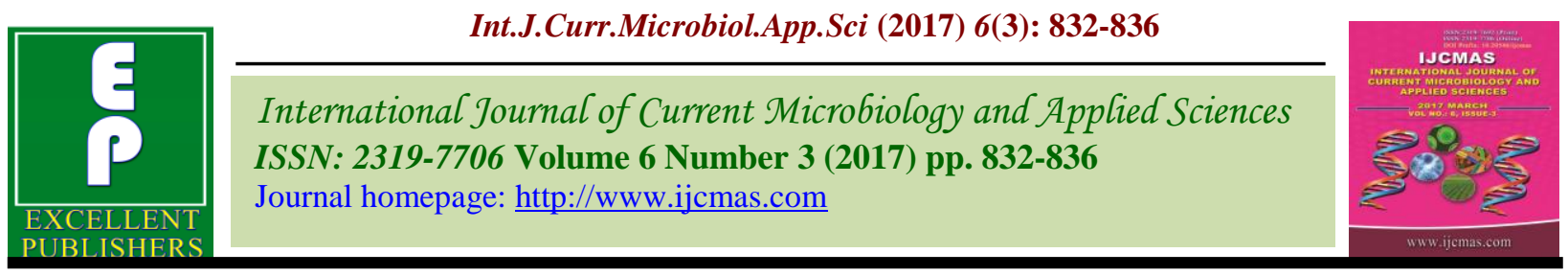

Original Research Article

https://doi.org/10.20546/ijcmas.2017.603.098

\title{
Genetic Analysis of Growth Rates of Nellore Brown Sheep
}

\author{
D. Vishnu Vardhan Reddy ${ }^{1}$, D. Sreenivas ${ }^{2}$, M. Gnanaprakash ${ }^{3}$ and Ch. Harikrishna ${ }^{4}$ \\ ${ }^{1}$ Department of Animal Genetics and Breeding, college of veterinary science, SVVU, \\ Proddatur, Kadapa district, Andhrapradesh-516360 \\ ${ }^{2}$ Department of Animal Genetics and Breeding, College of Veterinary Science, \\ P.V. Narsimha Rao Telangana Veterinary University, Korutla, Karimnagar, Telangana-505326 \\ ${ }^{3}$ Poultry Research Station, College of Veterinary Science, P.V. Narsimha Rao \\ TelanganaVeterinary University, Rajendranagar, Hyderabad-500030 \\ ${ }^{4}$ Livestock Research Station, P.V. Narsimha Rao TelanganaVeterinary University, \\ Mamnoor, Warangal, Telangana - 506166 \\ *Corresponding author
}

\section{A B S T R A C T}

The data on body weights at birth, 3, 6, 9 and 12 months of age recorded on 519 Nellore Brown lambs born during 2009 to 2013 maintained at Livestock Research

\section{Keywords}

Nellore Brown sheep, Average daily gain, Nongenetic factors, Heritability.

\section{Article Info}

\section{Accepted:}

15 February 2017

Available Online:

10 March 2017 Station, Mamnoor, Warangal district which is a constituent of Sri P.V. Narsimha Rao Telangana Veterinary University, Hyderabad, were utilized for the present study. The overall least squares means for average daily gains during $0-3\left(\mathrm{ADG}_{1}\right), 3-6\left(\mathrm{ADG}_{2}\right)$, 6$9\left(\mathrm{ADG}_{3)}\right.$ and $9-12\left(\mathrm{ADG}_{4}\right)$ months of ages were $109.90 \pm 0.28,84.80 \pm 0.23,45.53 \pm$ 0.20 and $31.29 \pm 0.25 \mathrm{~g}$, respectively. The growth rate decreased as the age advanced and was the lowest during 9-12 months. They ear of birth had highly significant $(\mathrm{P} \leq 0.01)$ effect on the average daily gains at 0-3 and 9-12 months of age. The effect of season of birth was non-significant $(\mathrm{P} \leq 0.05)$ on the average daily gains at all ages studied. Males recorded significantly $(\mathrm{P} \leq 0.01)$ higher average daily gains than the females at all ages studied. The estimates of heritabilities of ADGs ranged from $0.02 \pm 0.06$ to $0.20 \pm 0.11$.The estimates of heritabilities for ADGs indicated that non genetic factors play an important role and better feeding and management can help to improve these traits.

\section{Introduction}

Small ruminants have become the most promising livestock in the country due to ample marketing opportunities for their products. Sheep farming is a major source of income and livelihood of small and marginal farmers of arid and semi-arid regions of India besides providing nutritional security to the rural people. Sheep are efficient converters of unutilized poor quality grass and crop residues into meat and skin. In small ruminants, fast growth rate ultimately determines their meat producing capability up to marketing age and therefore, affects economic success of producing system (Abbasi et al., 2012). With the rising prices of mutton in the market, fast growing and heavier lambs in great demand (Narula et al., 2009). 
Nellore is a popular and tallest mutton breed in the country distributed predominantly in Nellore and Prakasam districts of Andhra Pradesh. Nellore is also known for heat tolerance, disease resistance and thrives well in harsh conditions. Based on coat color pattern Nellore sheep is classified into three varieties viz. Palla, Jodipi and Brown or Dora. There is no information available on the growth performance of Nellore Brown sheep. Therefore present study was under taken to study the growth performance of Nellore Brown sheep under organized farm conditions.

\section{Materials and Methods}

The data on body weights at birth, 3, 6, 9 and 12 months of age recorded on 519 Nellore Brown lambs of 22 sires born during 2009 to 2013 maintained at Livestock Research Station, Mamnoor, Warangal district which is a constituent of Sri P.V. Narsimha Rao Telangana Veterinary University, Hyderabad, were utilized for the present study. The animals were maintained on semi-intensive system with a provision of concentrates supplementation (250-300g/day/animal) and 8hours grazing. Water is provided ad libitum in the farm and grazing areas. Lambs were weaned at the age of 3 months.

Absolute growth rate is the change in size over time and calculated as (yt2 - yt 1$) /(\mathrm{t} 2-$ t1) where y refers to body weight and t1 and t2 refers to age in days (Fitzhugh and Taylor, 1971). Absolute growth rate is often called as average daily gain (ADG) which is expressed in grams per day.

The least squares analysis of variance technique using mixed model least-squares and maximum likelihood computer program pc-2 developed by Harvey (1990) was applied to study the influence of various non-genetic factors such as season, year of birth and sex on body weights.
The data were analysed using the following statistical model

$Y_{i j k l}=\mu+Y_{i}+S e_{j}+S_{k}+e_{i j k l}$

Where,

$\mathrm{Y}_{\mathrm{ijkl}}=$ observation on $1^{\text {th }}$ individual belonging to $\mathrm{k}^{\text {th }}$ sex, $\mathrm{j}^{\text {th }}$ season of birth and $\mathrm{i}^{\text {th }}$ year.

$\mu=$ Overall mean

$Y_{i}=$ Effect of $i^{\text {th }}$ year $(i=1$ to 5 i.e., 20092013)

$\mathrm{Se}_{\mathrm{j}}=$ Effect of $\mathrm{j}^{\text {th }}$ season of birth $(\mathrm{j}=1$ and 2 i.e., $1=$ April-June and $2=$ October- December) $\mathrm{S}_{\mathrm{k}}=$ Effect of $\mathrm{k}^{\text {th }}$ sex $(\mathrm{k}=1$ and 2: i.e., male and female)

$\mathrm{e}_{\mathrm{ijkl}}=$ Random error associated with $1^{\text {th }}$ individual and assumed to be normally and independently distributed with mean 0 and variance $\sigma_{\mathrm{e}}^{2}$.

Duncan's Multiple Range Test (D.M.R.T) as modified by Kramer (1957) was used for comparing the sub-group means. Heritability Estimates were computed for various traits based on the data adjusted for non-genetic effects by paternal half-sib correlation method as per Becker (1985).

\section{Results and Discussion}

The overall least squares means for average daily gains during $0-3\left(\mathrm{ADG}_{1}\right), 3-6\left(\mathrm{ADG}_{2}\right)$, 6$9\left(\mathrm{ADG}_{3}\right)$ and $9-12\left(\mathrm{ADG}_{4}\right)$ months of ages were $109.90 \pm 0.28,84.80 \pm 0.23,45.53 \pm$ 0.20 and $31.29 \pm 0.25 \mathrm{~g}$, respectively (Table 1). The growth rate decreased as the age advanced and was the lowest during 9-12 months. This decline in ADG could be attributed to the reason of advancing maturity (Jeichitra and Rajendran, 2013). The ADGs recorded in the present study coincided with the findings of Mandal et al., (2003) in Muzaffarnagari sheep; Narula et al., (2009) and Joshi et al., (2014) in Magra sheep but 
higher than that of the reported in Nali sheep by Dey and Poonia (2005), in Madras Red sheep by Balasubramanyam et al., (2010) and in Mecheri sheep by Jeichitra and Rajendran (2013).

The least squares analysis of variance revealed that the year of birth had highly significant $(\mathrm{P} \leq 0.01)$ effect on the average daily gains at 0-3 and 9-12 months of age. The differences in agro-climatic conditions and management factors could be the reason for variations in average daily gains among different years. Similar findings were reported by Dey and Poonia (2005) in Nali lambs;
Narula et al., (2009) in Magra sheep and Ganesan et al., (2013) in Madras Red sheep.

The effect of season of birth was nonsignificant $(\mathrm{P} \leq 0.05)$ on the average daily gains at all ages studied. The least squares means for average daily gains at 0-3, 3-6, 6-9 and 9-12 months of age were $109.76 \pm 0.41$, $85.12 \pm 0.34,45.62 \pm 0.29$ and $31.62 \pm 0.38 \mathrm{~g}$, respectively in offseason born lambs while in main season lambs the daily gains were $110.04 \pm 0.31,84.48 \pm 0.26,45.44 \pm 0.22$ and $30.96 \pm 0.28 \mathrm{~g}$, at the corresponding ages(Table1).

Table.1 Least- squares means $( \pm \mathrm{SE})$ of average daily gains (g/day) in Nellore Brown sheep

\begin{tabular}{|c|c|c|c|c|c|}
\hline Effects & $\begin{array}{c}\text { No of } \\
\text { observations }\end{array}$ & $\begin{array}{c}\mathrm{ADG}_{1} \\
(\mathbf{0}-3 \mathrm{M})\end{array}$ & $\begin{array}{c}\mathrm{ADG}_{2} \\
(3-6 M)\end{array}$ & $\begin{array}{c}\mathrm{ADG}_{3} \\
(6-9 M)\end{array}$ & $\begin{array}{c}\mathrm{ADG}_{4} \\
(9-12 M)\end{array}$ \\
\hline Overall mean & 519 & $109.90 \pm 0.28$ & $84.80 \pm 0.23$ & $45.53 \pm 0.20$ & $31.29 \pm 0.25$ \\
\hline Year & & $* *$ & NS & NS & $* *$ \\
\hline 2009 & 61 & $110.48^{\mathrm{a}} \pm 0.68$ & $84.46 \pm 0.57$ & $46.02 \pm 0.48$ & $32.52^{\mathrm{a}} \pm 0.62$ \\
\hline 2010 & 39 & $110.76^{\mathrm{a}} \pm 0.80$ & $84.18 \pm 0.67$ & $45.92 \pm 0.57$ & $30.52^{b c} \pm 0.73$ \\
\hline 2011 & 99 & $109.74^{\mathrm{a}} \pm 0.51$ & $85.43 \pm 0.43$ & $45.49 \pm 0.36$ & $30.31^{c} \pm 0.46$ \\
\hline 2012 & 197 & $108.28^{\mathrm{b}} \pm 0.35$ & $85.28 \pm 0.29$ & $45.17 \pm 0.25$ & $31.96^{\mathrm{ab}} \pm 0.32$ \\
\hline 2013 & 123 & $110.25^{\mathrm{a}} \pm 0.43$ & $84.65 \pm 0.36$ & $45.05 \pm 0.31$ & $31.14^{\mathrm{abc}} \pm 0.39$ \\
\hline Season & & NS & NS & NS & NS \\
\hline $\begin{array}{l}\text { Off-season } \\
\text { (April-June) }\end{array}$ & 172 & $109.76 \pm 0.41$ & $85.12 \pm 0.34$ & $45.62 \pm 0.29$ & $31.62 \pm 0.38$ \\
\hline $\begin{array}{l}\text { Main season } \\
\text { (Oct- Dec) }\end{array}$ & 347 & $110.04 \pm 0.31$ & $84.48 \pm 0.26$ & $45.44 \pm 0.22$ & $30.96 \pm 0.28$ \\
\hline Sex & & $* *$ & $* *$ & $* *$ & $* *$ \\
\hline Male & 203 & $127.20^{\mathrm{a}} \pm 0.42$ & $91.71^{\mathrm{a}} \pm 0.35$ & $48.64^{\mathrm{a}} \pm 0.30$ & $33.44^{\mathrm{a}} \pm 0.39$ \\
\hline Female & 316 & $92.60^{\mathrm{b}} \pm 0.30$ & $77.89^{\mathrm{b}} \pm 0.25$ & $42.42^{\mathrm{b}} \pm 0.21$ & $29.14^{\mathrm{b}} \pm 0.27$ \\
\hline
\end{tabular}

Significant $(\mathrm{P} \leq 0.05) ;{ }^{* *}$ Significant $(\mathrm{P} \leq 0.01)$; NS-Non Significant; Means followed by the same super script(s) do not differ significantly $(\mathrm{P} \leq 0.05)$ 
Table.2 Heritability estimates of average daily gains of Nellore Brown sheep

\begin{tabular}{|c|c|}
\hline Trait & Estimate \pm SE \\
\hline ADG $_{1}(0-3 M)$ & $0.04 \pm 0.06$ \\
\hline ADG $_{2}(3-6 M)$ & $0.02 \pm 0.06$ \\
\hline ADG $_{3}(6-9 M)$ & $0.15 \pm 0.09$ \\
\hline ADG $_{4}(9-12 M)$ & $0.25 \pm 0.12$ \\
\hline
\end{tabular}

However, significant effect of season of birth on average daily gains was reported by Ganesan et al., (2013) in Madras Red sheep and Jeichitra and Rajendran (2013) observed season of birth significantly affected the post weaning gains in Mecheri sheep.

Males recorded significantly $(\mathrm{P} \leq 0.01)$ higher average daily gains than the females at all ages studied. The least squares means for average daily gains during 0-3,3-6, 6-9 and 912 months of age were $127.20 \pm 0.42,91.71 \pm$ $0.35,48.64 \pm 0.30$ and $33.44 \pm 0.39 \mathrm{~g}$ in males and $92.60 \pm 0.30,77.89 \pm 0.25,42.42 \pm$ $0.21,29.14 \pm 0.27 \mathrm{~g}$ in females, respectively (Table 1). The present findings indicated that male lambs gained more weights than female lambs during all stages of growth period and the variation in average daily gains at all ages in both sexes might be attributed to differences in the hormonal profiles and physiological differences. Present findings for the effect of sex are similar to the reports of Dey and Poonia (2005a) in Nali sheep; Narula et al., (2009) in Magra sheep and Jeichitra and Rajendran (2013) in Mecheri sheep.

The estimates of heritabilities for average daily gains during $0-3,3-6,6-9$ and 9-12 months of ages were $0.04 \pm 0.06,0.02 \pm 0.06$, $0.15 \pm 0.09$ and $0.20 \pm 0.11$, respectively (Table 2). The estimates ranged from low to moderate. The heritability of ADGs increased from birth to 12 months.However, the estimate may be inflated upwards as maternal effect is more pronounced up to weaning and thus, this may not be the true additive value and maybe containing a proportion of additive maternal effect in it (Ganai et al., 2010). The moderate heritability estimates for ADGs is indicative of genetic improvement in these traits through selection. The average daily gains between 9 12 months age may be taken as criterion fors election. Higher heritability estimates were reported by Ganesan et al., (2013) in Madras Red sheep and Joshi et al., (2014) in Magra sheep. The estimates of heritabilities for ADGs indicated that non genetic factors play an important role and better feeding and management can help to improve these traits.

\section{Acknowledgements}

Thanks to Head of Livestock Research Station,P.V. Narsimha Rao Telangana Veterinary University, Mamnoor, Warangal, Telangana for permitting and providing necessary data for research work.

\section{References}

Abbasi, M.A., Abdollahi-Arpanahi, R., Maghsoudi, A., Torshizi, R. V., \& Nejati-Javaremi, A. 2012. Evaluation of models for estimation of genetic parameters and maternal effects for early growth traits of Iranian Baluchi sheep. Small Ruminant Res., 104(1): 6269.

Balasubramanyam, D., Jaishankar, S., Kathiravan, P., \&Sivaselvam, S.N. 2011. Performance of Madras Red Sheep under farmer's flocks. Indian $J$. Field Vet., 6(3): 5-8.

Becker, W.A. 1985. Manual of Quantitative Genetics. Program in Genetics 
Washington State University, USA.

Dey, B., \& Poonia, J.S. 2005. Factors affecting growth traits in Nali sheep. Indian J. Small Ruminants, 11(1): 77-79.

Fitzhugh, H.A., \& Taylor, S. 1971. Genetic analysis of degree of maturity. $J$. Animal Sci., 33(4): 717-725.

Ganai, T.A.S., Misra, S.S., \& Sheikh, F.D. 2010. Genetic parameters and variance component estimates of body weight of Corriedale sheep. Indian J. Small Ruminants, 16(2): 236-239.

Ganesan, R., Dhanavanthan, P., Balasubramanyam, D., \& Kumarasamy, P. Estimates of genetic parameters of growth traits in Madras Red sheep. IOSR J. Agri. Vet. Sci., 3(5): 69-73.

Harvey, W.R. 1990. User's Guide for LSMLMW and MIXMDL PC-2 version. Mixed model least-squares and maximum likelihood computer program, Ohio State University,
Columbus, Ohio, USA.

Jeichitra, V., \& Rajendran, R. 2013. Effect of Non-Genetic Factors on Post Weaning Average Daily Gains in Mecheri Sheep. Int. J. Livestock Res., 3(2): 169173.

Joshi, R.K., Narula, H.K., Singh, H., \& Chopra, A. 2014. Heritability estimates of growth traits in Magra sheep. Indian J. Small Ruminants, 20(2); 109-111.

Kramer, C.Y. 1957. Extension of multiple range tests to group correlated adjusted means. Biometrics, 13(1); 13-18.

Mandal, A., Pant, K.P., Nandy, D.K., Rout, P.K., \& Roy, R. 2003.Genetic analysis of growth traits in Muzaffarnagari sheep. Trop. Animal Health Production, 35(3): 271-284.

Narula, H.K., Yadav, S.B.S., Sharma, P.R., \& Mehrotra, V. 2009. Growth and reproductive performance of Magra sheep of Rajasthan. Indian J. Animal Sci., 79(6): 639-641.

\section{How to cite this article:}

Vishnu Vardhan Reddy, D., D. Sreenivas, M. Gnanaprakash and Harikrishna, Ch. 2017. Genetic Analysis of Growth Rates of Nellore Brown Sheep. Int.J.Curr.Microbiol.App.Sci. 6(3): 832-836. doi: https://doi.org/10.20546/ijcmas.2017.603.098 